\section{COMMEMORATING SIR DAVID HUGHES PARRY}

Dr R Gwynedd Parry of Swansea University gave a seminar at the Institute of Advanced Legal Studies on October 19, 2010 to mark the publication of David Hughes Parry - A Jurist in Society, which is his biography of Professor Sir David Hughes Parry QC published by University of Wales Press. Here is an edited transcript of his presentation at the seminar.

I should like to begin by thanking the Institute of Advanced Legal Studies and its Director, Professor Avrom Sherr, for the kind invitation to launch my biography of Sir David Hughes Parry.

How fitting it is that we should meet here to celebrate the life of one of the most remarkable Welshmen of the twentieth century. It is a place which was described by the late Professor Ash Wheatcroft as a "lasting memorial" to David Hughes Parry. Rightly so, as Hughes Parry's work in establishing and developing the Institute of Advanced Legal Studies as its founding director during those difficult yearly years was so crucial.

In 1947, during a time of great economic austerity, far worse than our own, David Hughes Parry exercised political influence within the corridors of power of the University of London to turn a long-held aspiration to establish a centre of excellence in advanced legal research into reality. It was no coincidence that the founding of this important institute coincided with Hughes Parry's term as vice-chancellor of the University of London. Perhaps the vision was not his originally - Lord Atkin and others had presented a compelling case for such an institute in the inter-war years. But it was Hughes Parry that converted that vision into a practical achievement.

Nobody else could have taken on the role of founding director with that practical "make do and mend" approach which was so essential at that moment in time. This pragmatic lawyer was a doer as much as a talker, and throughout his life made things happen while others, perhaps, found contentment in making their thoughts their aim. Of course, with this pragmatism came other traits: an ability to negotiate, make concessions, to strike a bargain, give and take, and flexibility. These were to be in Hughes Parry's toolbox throughout his public life.

Hughes Parry had made his name as professor of English law at the University of London, where, building on the work of his predecessor, Sir Edward Jenks, he gave leadership in developing the department of law at the London School and Economics into a centre of excellence in legal scholarship. Indeed, for many years he was the unofficial leader of the coalition of London law schools which also included those of University College and King's College. This coalition ensured that the University of London could rival the universities of Oxford and Cambridge as the intellectual powerhouse for English legal scholarship.

\section{Articles \\ Commemorating Sir David Hughes Parry \\ Judges, commerce and contract law \\ 1 \\ Case law relating to service provision changes under the Transfer of Undertakings (Protection of Employment) (TUPE) Regulations 2006 \\ Institute News \\ Articles (cont'd) \\ Colombia, conflict and the rule of law \\ The Gulf of Mexico Oil disaster: some legal issues \\ Sports contracts in Italy

Hughes Parry played the role of convenor and academic manager with great flair and skill. Indeed, he was such a canny operator in the world of university politics that he became not only vice-chancellor but also chairman of the Court of the University of London. Sometime vice-chairman of the University Grants Committee, he also chaired a commission which heralded the wholesale reform of the university system in New Zealand in 1959.

In his time, Hughes Parry was one of academia's elder statesmen. His career trajectory into the heights of academic management, however, would mean that his scholarly output would be a story of few and far between. Administration was to prove a considerable distraction in this legal scholar's professional journey and it meant that there was little space for pursuing personal intellectual interests. Then again, Hughes Parry's life story is more interesting and multi-faceted than merely that of an important jurist or university policy-maker and administrator: he was also a towering figure in the public life of Wales.

This biography of Sir David Hughes Parry is a project that has been driven by a sense of necessity. As a legal scholar, I felt there was a gap in legal literature which needed to be filled. Just as important, as a Welshman, I felt that an important figure in the social history of Wales had been neglected.

Hughes Parry had created for himself a distinctive role as legal advisor to the Welsh nation. His many contributions included those of president of the, then, University College of Wales, Aberystwyth, president of the Court of the National Eisteddfod and moderator of the General Assembly of the Presbyterian Church of Wales. However, at no time was the performance of the role of the nation's lawyer more important than during the years 1963-65, when he chaired a government committee whose task was to make recommendations on the legal status of the Welsh language. Hughes Parry was the chief architect of the report that led to the Welsh Language Act of 1967, which established in law the principle of equality between English 
and Welsh. This was to begin a process of restoring Welsh as a civic language, and the Welsh Language Measure recently enacted by the National Assembly of Wales is the latest stage in that process.

Yes, perhaps the need to record the life and reflect upon achievements of this notable Welsh lawyer provided the principal justifications for writing this book. But there may have been some rather more personal reasons behind its creation. Before I explain what they are, I should clarify one matter of detail.

A few years ago I gave a lecture on Hughes Parry to the Honourable Society of Cymmrodorion at the British Academy. A few weeks before I was due to give the lecture, I received a letter from the society's secretary confirming the arrangements, and saying how much he was looking forward to my lecture about my father. I replied to his letter, informing him that to the best of my knowledge and belief, I was not related to Sir David. I added that if he knew otherwise, I should like to know, as it might require a bit of re-writing on my part.

More seriously, Hughes Parry's name had existed in my sub-conscience since I was a child. On my father's bookcase was his autobiography, $O$ Bentref Llanaelhaearn i Ddinas Llundain, ("From the village of Llanaelhaearn to the city of London") in which he told the story of his upbringing, early years and his eventual journey from his home in rural north west Wales to London. My parents had been given a copy by Hughes Parry because my father was his minister at the end of his life, and, as I later found out, officiated at his funeral at Llanuwchllyn near Bala. Later, as a law student at Aberystwyth, I had studied a text, Parry and Clark on Succession, without knowing at the time that the first named author was that same fellow who had made the journey from Llanaelhaearn to London.

Having decided to assume the role of Hughes Parry's biographer, and as I embarked upon my research, I had no preconceptions of my subject or an agenda which I intended to pursue. The entire project has been driven by curiosity and a desire to find out, who was David Hughes Parry? What have I learnt from the experience? Firstly, that the biographer is more like a portrait painter than a chronicler of events. There is a need for the narrative account of the individual's life, certainly. The biographer is necessarily a recorder of past events in his subject's life. But, the biographer's function is more than this - it is to provide a portrait which facilitates understanding of the individual's character and which offers an insight into the subject's inner self.

Of course, there are obvious limitations to the exercise. The Welsh poet, Waldo Williams, in one of his poems asks the question "Beth yw byw? Cael neuadd fawr rhwng cyfyng furiau." The poet is asking "What is human life?" and replies that it is like a great and splendid hall within a confined space. In other words, individuals, with their imagination, their talent and potential, are far greater than the bodies which they inhabit. I feel the same about the narrow confines of this biography. Its modest canvas represents no more than an attempt to capture something of the essence of its subject whilst recognising that the subject's life in all its complexities is beyond the limits of the modest endeavour.

I have recorded some further thoughts about the potential of legal biography in a recent article in the Society of Legal Scholars' flagship journal, Legal Studies. I do hope that this study will make a small contribution to the canon of legal biography and to the wider discussion on the legal biography's role in deepening our understanding of the human, individual forces that can shape or influence legal development. Academic lawyers are at their most comfortable when dealing with abstractions, using the nomenclature of principles, norms and ideas. Yet legal principle has its human and social context and the legal biography can contribute towards the valuable task of contextualising the law and its development. With the LSE leading this debate with its excellent legal biography research project, I am sure that the legal biography will now be the subject of meaningful academic appraisal.

In addition to some appreciation of the value of legal biography, I have also learnt that the juristic vocation takes many forms and that one should not look for a typecast or a role-model. David Hughes Parry was a jurist who carved for himself a unique identity within the legal pantheon. Although his legal legacy is more pragmatic or operational than intellectual, he was a facilitator and enabler of important projects and ambitions. People like Hughes Parry matter. Without them, the thankless but indispensable job of academic management would have to be done by people with neither the desire nor the propensity for the task.

As I have already noted, Hughes Parry's individual story has a duality in that his life was divided between the academic affairs of the law and the public affairs of Wales. My study of David Hughes Parry has also been a personal meditation on what it means to be Welsh. Throughout his life Hughes Parry felt an obligation towards Wales, her language, culture and institutions. He took upon himself the mantle of one of Wales's guardians or elders, with an almost paternalistic responsibility for her welfare. Despite the several and demanding commitments in London, he would make inordinate sacrifices to attend various meetings and committees in Wales. Sometimes, these would be held midweek, when he would be required to travel from and return to London the very same day. This was not a joke, particularly in the 1950s and 1960s. One anecdote recalls how he travelled from London to attend an eisteddfod committee that was being held in rural Denbighshire in the middle of winter in order, it is rumoured, to keep an eye on the proceedings!

For his colleagues in the legal circles of London, this behaviour must have seemed perplexing. Yet, as a Welshman, I feel that I can empathise with it. Wales has this hold on her offspring that can defy cold reason and 
inspire behaviour which seems inexplicable to the outsider. Sir Thomas Parry Williams captured it in his poem "Hon", when he concluded, "ni allaf ddianc rhag hon" ("I cannot escape from her"). Perhaps the compulsion that drove Sir David Hughes Parry to that little eisteddfod committee is one which accounts for the endurance of the Welsh as a distinctive people and for which we should be grateful. 소

\section{R Gwynedd Parry}

LLB, PhD, FRHistS, Barrister

David Hughes Parry - A Jurist in Society (ISBN: 978070832292 5) is published in hardback by University of Wales Press, price $£ 48$.

\section{Articles for Amicus Curiae}

Amicus Curiae welcomes contributions, which should be accompanied by the name and contact details of the author. The journal publishes articles on a wide variety of issues, ranging from short pieces of 700-1,200 words and longer articles of 4,000 words of so (the upper limit can be extended where appropriate). Articles should be written in an informal style and without footnotes.

Anyone interested in submitting a piece should email Julian Harris (julian.harris@sas.ac.uk). 